\title{
In vitro Nematicidal Activity of Ten Plant Extracts Against Juveniles of Meloidogyne incognita
}

\author{
M. R. M. Saeed", G.A. M. Awadh ${ }^{*}$ M. A. Al-Thobhani* and Aziza Taj Al- Deen ${ }^{* \star}$ \\ *Department of Plant Protection, **Department of Horticulture and forestry, \\ Faculty of Agriculture, Sana'a University, Yemen. \\ E-mail: raweh2001@yahoo.com
}

\begin{abstract}
The nematicidal potential of aqueous leaf extracts of ten plant species distributed in agricultural lands in Yemen were assessed against second stage juveniles of Meloidogyne incognita in laboratory. The juveniles were exposed to 6 , 12, 24 and 48 hrs in three concentrations (12.5, 25 and 50\%) of leaf extracts. Leaf extracts of Datura stramonium, Peganum harmala, Datura innoxia, Argemone mexicana and Nicotiana glauca were effective in causing juvenile mortality, while leaf extracts of the other five plant species, Azadirachta indica, Catha edulis, Solanum incanum, Tagetes minuta and Withania somnifera showed no or little nematode mortality $(<30 \%)$ even at $50 \%$ concentration and $48 \mathrm{hrs}$ exposure time. The juveniles mortality was increased with increase of concentration and exposure time. Hundred percent juveniles mortality was observed at the modest concentration $(25 \%)$ of leaf extracts of D. stramonium and D. innoxia after 24 and $48 \mathrm{hrs}$, respectively. Whereas $100 \%$ mortality of juveniles was found at highest concentration $(50 \%)$ in leaf extract of $D$. stramonium after $12 \mathrm{hrs}$ and in leaf extracts of $D$. innoxia, $P$. harmala and $N$. glauca after 24 hrs or after 48 hrs in case of leaf extracts of $A$. mexicana. Leaf extract of $D$. stramonium achieved the highest mortality percentage at different concentrations and was significantly $(p \leq 0.05)$ superior over the rest of the extracts applied over time.
\end{abstract}

Keywords: Meloidogyne incognita, Nematicidal activity, Juveniles mortality, Leaf extracts.

\section{Introduction}

Plant parasitic nematodes are serious threats to crop production, causing significant yield losses (Sasser and Freckman, 1987). Among the plant-parasitic nematodes, are root-knot nematodes particularly Meloidogyne incognita Kofoid and White (Chitwood) causing crop losses of around 15\% alone in tropical countries (Sasser, 1979). Moreover, yield losses of $50-80 \%$ caused by these nematodes in vegetable crops are common (Siddiqi, 2000). In Yemen, it is one of the main pests in vegetables and fruit orchards, causing severe and significant yield losses, especially in polyhouses cultivations and nurseries (Saeed and Shawkat, 2014). The use of synthetic nematicides has been the most effective method of controlling 
plant-parasitic nematodes, but their cost and hazardous effect on human health, environment, ground water contamination and non-target organisms create a necessity to search new, cheap, eco-friendly and harmless methods of nematode control (Chitwood, 2003). In recent years, studies have shown the importance of natural nematicidal compounds in the plants themselves that have potential to suppress nematode populations (Sharma and Trivedi, 2002; Zasada et al., 2002; Banna et al., 2003; Neves et al., 2005; Awadh et al., 2008; Muniasamy et al., 2010; Pavaraj et al., 2010; Abdelnabby and Abdelrahman, 2012; Moosavi, 2012; Pavaraj et al., 2012 and Nelaballe and Mukkara, 2013). However, little attention has been drawn in Yemen towards the use of plant extracts as nematicides. Awadh et al., (2008) investigated in vitro the nematicidal effects of some plant extracts against Ditylenchus dipsaci.Also, Saeed and Shawkat, (2014) studied the nematicidal effect of some botanical powders and poultry manure against the root-knot nematode $M$. incognita in tomato plants under greenhouse conditions. Therefore, the present study was carried out to evaluate efficacy of some plant extracts in vitro against $\mathrm{J} 2$ of $M$. incognita.

\section{Materials and Methods}

\section{Plant collection:}

Fresh mature healthy leaves of Argemone mexicana, Datura innoxia, Datura stramonium, Nicotiana glauca, Peganum harmala, Solanum incanum,Tagetes minuta and Withania somnifera were collected from Sanaa University campus, while leaves of Azadirachta indica and Catha edulis were collected from Tehama and Al Hada regions, respectively. The collected leaves were washed under running tap water and spread for two weeks on polythene sheets on laboratory benches for air drying. The dried leaves were ground separately to coarse particles using DE motore and further grinding to fine powder was done using a Warring ${ }^{\circledR}$ electric blender and stored at room temperature in closed dark containers until use.

\section{Preparation of Plant Extracts:}

Aqueous extracts ( $10 \%$ concentration) were prepared by soaking $15 \mathrm{gm}$ of powdered leaves in $150 \mathrm{ml}$ of sterilized distilled water (SDW) and kept on a rotary shaker at 190-200 rpm for $24 \mathrm{hrs}$. Then, the mixture was filtered using Whatman ${ }^{\circledR}$ No. 1 filter paper and the residues were soaked and shaken by hand in $20 \mathrm{ml}$ distilled water for 5 minutes. The solution was filtered again and the first and second filtrates were mixed and freeze dried using freeze dryer system/lyph lock 4.5. All residues so obtained were kept in dark glass bottles in a freezer until use.

\section{Culture preparation:}

Adequate second stage juveniles (J2) of $M$. incognita were obtained from stock culture maintained on eggplant cv. Long purple in a glasshouse at the Faculty 
of Agriculture, Sana'a University. Only freshly hatched second stage juveniles collected within $48 \mathrm{hrs}$ were used in the study.

\section{Nematicidal Assay:}

Residue of each plant was dissolved in $50 \mathrm{ml}$ distilled water and out of which only $1 \mathrm{ml}$ was poured into $25 \mathrm{ml}$ beaker containing $4 \mathrm{ml}$ distilled water. This solution was considered as a stock solution (S/S) or $100 \%$ concentration. Dilutions of S/2 (50\%), S/4 (25\%) and S/8 (12.5\%) were freshly prepared by dilution with distilled water. Freshly hatched second stage juveniles of $M$. incognita were suspended in sterile distilled water. This suspension contained about 25 juveniles $/ 1 / 2 \mathrm{ml}$. For mortality assay, $1 / 2 \mathrm{ml}$ of $M$. incognita suspension was poured into autoclaved $5 \mathrm{~cm}$ Petri dishes and $2 \mathrm{ml}$ of each diluted plant extract concentration $(12.5 \%, 25 \%$ or $50 \%$ ) was added separately to Petri dishes. For control treatment, $2 \mathrm{ml}$ of distilled water was added to each Petri dish containing the nematode suspension. All the treatments were replicated thrice. Dead and survived juveniles were counted under a stereoscopic microscope after 6, 12, 24 and $48 \mathrm{hrs}$ of extract exposure. Percentage mortality was calculated from the number of $\mathrm{J}^{2 \mathrm{~s}}$ that did not move even after pricking the tail.

Data were subjected to ANOVA SPSS 21 software (SPSS Inc., Chicago, IL, USA) and significant differences among the treatments were portioned by Duncan's (1955) multiple range test at probability levels of $P=0.05$.

\section{Results}

Results in Table (1) show the effect of aqueous leaf extracts of ten plant species at different concentrations on mortality of $M$. incognita juveniles over time. The leaf extracts of five plant species, out of the ten tested, showed remarkable nematicidal effects against $M$. incognita. Percentage of juveniles mortality varied, according to the type of plant extract, concentration level and the exposure time. The juvenile mortality was increased with increase of concentration and exposure time. Leaf extracts of the five plant species viz., $D$. stramonium, $P$. harmala, D. innoxia, A. mexicana and $N$. glauca were effective in causing juvenile mortality, while leaf extracts of the other five plant species viz., $A$. indica, C. edulis, S. incanum, T. minuta and $W$. somnifera showed no or little nematode mortality $(<30 \%)$ even at $50 \%$ concentration and $48 \mathrm{hrs}$ exposure time. With plant species that showed remarkable nematicidal effect it could be noticed that the percentage of juveniles mortality was significantly increased with increase of the concentration over exposure time, except in case of $N$. glauca which caused no or little juveniles mortality when the concentration was increased from 12.5 to $25 \%$, while it achieved the highest mortality increase with increasing concentration to $50 \%$. 
Table (1): Effect of aqueous leaves extracts of ten plant species on mortality \% of second-stage juveniles (J2) of Meloidogyne incognita at different exposure time.

\begin{tabular}{|c|c|c|c|c|c|}
\hline \multirow{2}{*}{ Plant } & \multirow{2}{*}{$\begin{array}{c}\text { Concentration } \\
\qquad(\%)\end{array}$} & \multicolumn{4}{|c|}{ Mortality (\%) } \\
\hline & & $6 h$ & $12 \mathrm{~h}$ & $24 h$ & $48 h$ \\
\hline \multirow{3}{*}{ Argemone mexicana } & 12.5 & ${ }^{*} 0 \pm 0 \mathrm{~g}$ & ${ }^{*} 0 \pm 0 \mathrm{~g}$ & ${ }^{*} 5 \pm 0 \mathrm{ijk}$ & *10 \pm 7 ghijk \\
\hline & 25 & $21 \pm 4 f$ & $35 \pm 2 \mathrm{e}$ & $63 \pm 1 c$ & $77 \pm 6 c$ \\
\hline & 50 & $42 \pm 11 d$ & $88 \pm 2 b$ & $98 \pm 4 a$ & $100 \pm 0 a$ \\
\hline \multirow{3}{*}{ Azadirachta indica } & 12.5 & $0 \pm 0 \mathrm{~g}$ & $0 \pm 0 \mathrm{~g}$ & $0 \pm 0 \mathrm{k}$ & $6 \pm 3 \mathrm{jk}$ \\
\hline & 25 & $0 \pm 0 \mathrm{~g}$ & $0 \pm 0 \mathrm{~g}$ & $0 \pm 0 \mathrm{k}$ & $8 \pm 4 \mathrm{ijk}$ \\
\hline & 50 & $0 \pm 0 \mathrm{~g}$ & $0 \pm 0 \mathrm{~g}$ & $2 \pm 3 k$ & $17 \pm 9$ fghi \\
\hline \multirow{3}{*}{ Catha edulis } & 12.5 & $0 \pm 0 \mathrm{~g}$ & $0 \pm 0 \mathrm{~g}$ & $0 \pm 0 \mathrm{k}$ & $0 \pm 0 \mathrm{k}$ \\
\hline & 25 & $0 \pm 0 \mathrm{~g}$ & $0 \pm 0 \mathrm{~g}$ & $0 \pm 0 \mathrm{k}$ & $0 \pm 0 \mathrm{k}$ \\
\hline & 50 & $0 \pm 0 \mathrm{~g}$ & $0 \pm 0 \mathrm{~g}$ & $5 \pm 0$ hijk & $24 \pm 5$ ef \\
\hline \multirow{3}{*}{ Datura innoxia } & 12.5 & $0 \pm 0 \mathrm{~g}$ & $2 \pm 3 g$ & $15 \pm 2$ ef & $36 \pm 3 d$ \\
\hline & 25 & $8 \pm 3 \mathrm{~g}$ & $52 \pm 11 d$ & $73 \pm 9 b$ & $100 \pm 0 \mathrm{a}$ \\
\hline & 50 & $58 \pm 4 c$ & $86 \pm 4 b$ & $100 \pm 0 \mathrm{a}$ & $100 \pm 0 \mathrm{a}$ \\
\hline \multirow{3}{*}{ Datura stramonium } & 12.5 & $0 \pm 0 \mathrm{~g}$ & $8 \pm 4 f$ & $28 \pm 0 d$ & $36 \pm 12 d$ \\
\hline & 25 & $58 \pm 1 c$ & $86 \pm 3 b$ & $100 \pm 0 \mathrm{a}$ & $100 \pm 0 \mathrm{a}$ \\
\hline & 50 & $82 \pm 6$ a & $100 \pm 0 \mathrm{a}$ & $100 \pm 0 \mathrm{a}$ & $100 \pm 0 \mathrm{a}$ \\
\hline \multirow{3}{*}{ Nicotiana glauca } & 12.5 & $0 \pm 0 \mathrm{~g}$ & $5 \pm 0 \mathrm{fg}$ & $16 \pm 1$ ef & $24 \pm 2$ ef \\
\hline & 25 & $0 \pm 0 \mathrm{~g}$ & $9 \pm 4 f$ & $17 \pm 1$ e & $34 \pm 7 d$ \\
\hline & 50 & $32 \pm 4$ e & $85 \pm 4 b$ & $100 \pm 0 \mathrm{a}$ & $100 \pm 0 \mathrm{a}$ \\
\hline \multirow{3}{*}{ Peganum harmala } & 12.5 & $3 \pm 4 \mathrm{~g}$ & $5 \pm 0 \mathrm{fg}$ & $11 \pm 1 \mathrm{fgh}$ & $16 \pm 1 \mathrm{fghi}$ \\
\hline & 25 & $43 \pm 7 d$ & $60 \pm 10 \mathrm{c}$ & $76 \pm 7 b$ & $91 \pm 7 b$ \\
\hline & 50 & $72 \pm 6 b$ & $90 \pm 3 b$ & $100 \pm 0$ a & $100 \pm 0 \mathrm{a}$ \\
\hline \multirow{3}{*}{ Solanum incanum } & 12.5 & $0 \pm 0 \mathrm{~g}$ & $0 \pm 0 \mathrm{~g}$ & $0 \pm 0 \mathrm{k}$ & $16 \pm 2$ fghi \\
\hline & 25 & $0 \pm 0 \mathrm{~g}$ & $0 \pm 0 \mathrm{~g}$ & $3 \pm 4 j k$ & $19 \pm 7 \mathrm{fg}$ \\
\hline & 50 & $0 \pm 0 \mathrm{~g}$ & $2 \pm 3 \mathrm{fg}$ & $9 \pm 0$ ghij & $30 \pm 1$ de \\
\hline \multirow{3}{*}{ Tagetes minuta } & 12.5 & $0 \pm 0 \mathrm{~g}$ & $4 \pm 0 \mathrm{fg}$ & $6 \pm 3 h i j k$ & $8 \pm 0$ hijk \\
\hline & 25 & $0 \pm 0 \mathrm{~g}$ & $6 \pm 2 \mathrm{fg}$ & $10 \pm 2$ ghi & $14 \pm 2$ ghij \\
\hline & 50 & $2 \pm 3 \mathrm{~g}$ & $10 \pm 2 f$ & $13 \pm 1$ efg & $17 \pm 1 \mathrm{fgh}$ \\
\hline \multirow{3}{*}{ Withania somnifera } & 12.5 & $0 \pm 0 \mathrm{~g}$ & $0 \pm 0 \mathrm{~g}$ & $0 \pm 0 \mathrm{k}$ & $0 \pm 0 \mathrm{k}$ \\
\hline & 25 & $0 \pm 0 \mathrm{~g}$ & $0 \pm 0 \mathrm{~g}$ & $0 \pm 0 \mathrm{k}$ & $0 \pm 0 \mathrm{k}$ \\
\hline & 50 & $0 \pm 0 \mathrm{~g}$ & $0 \pm 0 \mathrm{~g}$ & $5 \pm 0$ hijk & $17 \pm 4 \mathrm{fgh}$ \\
\hline Control & 0 & $0 \pm 0 \mathrm{~g}$ & $0 \pm 0 \mathrm{~g}$ & $0 \pm 0 \mathrm{k}$ & $0 \pm 0 \mathrm{k}$ \\
\hline
\end{tabular}

Means in each column followed by the same letter (s) are not significant at $\mathrm{P} \leq 0.05$ according to Duncan's multiple range test.

* Mean \pm standard deviation 
Leaf extract of $D$. stramonium achieved the highest mortality percentage at different concentrations and was significantly superior over the rest of the extracts applied over time. Significant mortality was found in leaf extract of the five plant species that showed nematicidal effect, except in case of lowest concentration of $D$. stramonium after $6 \mathrm{hrs} ; D$. innoxia, N. glauca and $P$. harmala after 6 and $12 \mathrm{hrs,}$ and after all exposure time for $A$. mexicana, and after $6 \mathrm{hrs}$ at modest concentration of $D$. innoxia and $N$. glauca. On the other hand, insignificant mortality percentages were found in leaf extracts of the other 5 plant species, except in case of $A$. indica, $C$. edulis and $W$. somnifera at the highest concentration after $48 \mathrm{hrs}$; $S$. incanum at highest concentration after $24 \mathrm{hrs}$ and at the other concentrations after $48 \mathrm{hrs}$; and T. minuta at highest concentration after $12 \mathrm{hrs}$ and after 24 and $48 \mathrm{hrs}$ at modest or highest concentrations.

Hundred percent juveniles mortality was observed at the modest concentration $(25 \%)$ of leaf extract of $D$. stramonium and $D$. innoxia after 24 and 48hrs, respectively. Whereas $100 \%$ mortality of juveniles was found at highest concentration $(50 \%)$ in leaf extract of $D$. stramonium after $12 \mathrm{hrs}$ and in leaf extracts of $D$. innoxia, $P$. harmala and $N$. glauca after $24 \mathrm{hrs}$ or after $48 \mathrm{hrs}$ in case of leaf extract of $A$. mexicana.

At lowest concentration (12.5\%) leaf extracts of the tested plants found to be no or less active in nematicidal activity causing only $37 \%$ as a highest mortality after $48 \mathrm{hrs}$ for $D$. stramonium and $D$. innoxia. At modest concentration (25\%) leaf extracts of $D$. stramonium exhibited the highest mortality (58\%) after 6 hrs followed by $P$. harmala and $A$. mexicana with 43 and $21 \%$ mortality, respectively. Lowest mortality $8 \%$ was obtained by $D$. innoxia, while the rest extracts showed no mortality at the same exposure time. After 12 and $24 \mathrm{hrs}$ the highest values mortality (86 and $100 \%$ ) were achieved by $D$. stramonium followed by $P$. harmala, $D$. innoxia and $A$. mexicana with (60 \& 76\%), (53 \& 73\%) and (35 \& 63\%), respectively. $D$. stramonium and $D$. innoxia gave $100 \%$ mortality after $48 \mathrm{hrs}$ followed by $P$. harmala and $A$. mexicana with 91 and $77 \%$, mortality, respectively. At highest concentration (50\%) leaf extracts of $D$. stramonium achieved the highest mortality (82\%) after 6 hrs followed by $P$. harmala, $D$. innoxia and $A$. mexicana with 72,58 and $42 \%$ mortality, respectively. After $12 \mathrm{hrs} 100 \%$ juveniles mortality was observed only in leaf extract of $D$. stramonium followed by leaf extracts of $P$. harmala $(90 \%), A$. mexicana (88\%), D. innoxia (86\%) and N. glauca (85\%). Whereas $100 \%$ juveniles mortality was observed in leaf extracts of the five effective plants after 24 and $48 \mathrm{hrs}$, except in case of leaf extract of $A$. mexicana after $24 \mathrm{hrs}$ which caused $98 \%$ mortality.

\section{Discussion}

The obtained results indicated that the aqueous leaf extracts of $D$. stramonium, P. harmala, D. innoxia, A. mexicanai and N. glauca had nematicidal 
activity against $M$. incognita. Leaf extracts of the other tested plant species ( $A$. indica, C. edulis, S. incanum, T. minuta and W. somnifera) showed no or low juveniles mortality. A positive correlation was found between the juveniles mortality and each of the extract concentration and the exposure time. Extracts of Datura species were more effective by increasing the exposure time being the most effective extract. Aqueous leaf extract of $D$. stramonium significantly showed the highest percentage of juvenile mortality, as it caused $100 \%$ mortality after only 12 hrs of exposure time at highest concentration level and after $24 \mathrm{hrs}$ at modest one. These results are in agreement with those obtained by Nandal and Bhati (1986); Sellami and Mouffarrah, (1994); Akhtar and Farzana (1996); Prasad et al. (2002); Elbadria (2008) and Chaudhary et al. (2013) who reported that $D$. stramonium caused the highest mortality percentage in comparsion with other tested plants. Phytochemical analysis revealed that this plant is rich in alkaloids atropine, meteloidine, nicotine, scopolamine, hyoscyamine, terpenoids and flavonoids which have high rate of nematicidal activity (Shahwar et. al., 1995 and Pavela, 2004). The alkaloids killed 90 to $100 \%$ of Hoplolaimus indicus, Helicotylenchus multicinctus, and M. incognita (Qamar et al., 1995). Our results could prove that aqueous leaf extracts of $P$. harmala, $A$. mexicana and $N$. glauca contain active ingredients that exhibit strong nematicidal properties. Nematicidal activity of $P$. harmala and $A$. mexicana was noticed at modest and highest concentrations, while that of $N$. glauca was only noticed at highest concentration. These findings are similar to other results in previous reports (Mojumdar and Mishra, 1991; Shaukat et al., 2002; Patel et al., 2004; El Allagui et al., 2007; Abdelnabby and Abdelrahman 2012; Parihar et al., 2012; Rizvi et al., 2012; ElHassan et al., 2013; Sholevarfard and Moosavi, 2015).

The bioactivity of $P$. harmala against nematodes may be attributed to the presence of the alkaloids in its leaves including $\beta$-carboline, harmine, harmaline, harmalol, harmol and harman and quinazolines as vascine and vasicinone (ElHassan et al., 2013; and Moloudizargari et al., 2013). Nematicidal activity of $A$. mexicana might be attributed to its contents of alkaloids (berberine, protopine, sarguinarine, coptisine, chelerytherine), amino acids, phenolics, fatty acids (myristic, palmitic, oleic, linoleic acids) and triglyceride (sn-glycerol-1-eicosa-9,12dienoate-2-palmitoleate-3-linoleate) (Saleh et al., 1987; Mojumdar and Mishra, 1991; Facchini, 2001 and Shaukat et al., 2002). In case of N. glauca, the biological activity can be attributed to presence of nicotine, and piperidine alkaloid, which can be toxic in high doses to both animals and human. Because of its ability in water it could explain the high affectivity of its water extracts (Webb and Dalzell, 1997). Also, it contains anabasine, as a highly toxic piperidine like alkaloid constituting about $70 \%$ of the plant as a whole (Mizrachi et al., 2000 and Mhinana et al., 2010).

Neem (A. indica) and marigold ( $T$. minuta) have been certified as biological 
nematicides by various researchers and used extensively all over the world (Good et al., 1965; Pluke et al., 1999; Akhtar and Malik, 2000; Chitwood, 2002; Ferraz and de Freitas, 2004; Javed et al., 2007a,b; Adegbite, 2011; Nelaballe and Mukkara, 2013), but in our results leaf extracts of these plants exhibited no or very little juveniles mortality even at the highest concentration level. A possible explanation for this may be that most studies on the use of neem and miragold leaf extracts in nematode control used high concentrations (Agbenin et al., 2005, Akpheokhai et al., 2012 and Chaudhary et al,. 2013). These concentrations were many times higher than concentrations of neem and miragold extracts used in this study. Zongo et al. (1993) reported that the concentration of active ingredients present in leaf extracts may differ according to environmental conditions, geographical area and the year of collection. Tibugari, et al. (2012) postulated that active ingredients may be lost during air drying and preparing process of powder extracts.

The nematicidal potential of leaf extracts of $W$. somnifera and $S$. incanum were very little, but some previous studies found that extracts of $W$. somnifera (Goel et al., 2005; Khan et al., 2008; Parihar et al., 2012) and S. incanum (Akhtar and Farzana, 1996) were effective in causing juvenile mortality. C. edulis is one of the most cultivated plant in Yemen. It is a good resistant plant to many pests and diseases. The present study is the first report on the evaluation of its leaf extract for their nematicidal activity against the root knot nematode, $M$. incognita. Only at the highest concentration after $48 \mathrm{hrs}$ it significantly caused low mortality percentage (24\%).

In this study, leaf extracts of five plants, namely; D. stramonium, P.harmala, $D$. innoxia, A. mexicana and $N$. glauca have the potential in controlling the root- knot nematodes and can be efficiently used as soil amendments. Future research should be focused on micro plot and field experiments, along with assessment the combination use of these amendments with other controlling methods.

\section{References}

Abdelnabby, H. M. and Abdelrahman, S. M. (2012). Nematicidal activity of selected flora of Egypt. Egypt. J. Agronematol., Vol. 11, No.1, PP. $106-$ 124.

Adegbite, A. A. (2011). Effects of some indigenous plant extracts as inhibitors of egg hatch in root-knot nematode (Meloidogyne incognita race 2). American J. of Experimental Agric., 1:96-100.

Agbenin, N. O.; Emechebe, A. M.; Marley, P. S. and Akpa, A. D. (2005). Evaluation of nematicidal action of some botanicals on Meloidogyne incognita in vivo and in vitro. J. of Agric. and Rural Development in the Tropics and Subtrop., 106(1):29-39. 
Akhtar, M. and Farzana, B. (1996): Evaluation of nematicidal properties of some members of the family Solanaceae. Biores. Technol., 57: 95-97.

Akhtar, M. and Malik, A. (2000). Role of organic soil amendments and soil organisms in the biological control of plant-parasitic nematodes: a review. Biores. Technol., 74, 35-47.

Akpheokhai, I.L.; Claudius-Cole, A. O. and Fawol B. (2012). Evaluation of some plant extracts for the management of Meloidogyne incognita on soybean (Glycine max). World J. of Agric. Sci., 8 (4): 429-435.

Awadh, G. M.; Saeed, M. R.; Najy, A. and Saleh, A. M. ( 2008). In-vitro nematicidal activity of some selected plants on stem nematode Ditylenchus dipsaci f. (Tylenchida: Tylenchidae). Yemeni J. of Biological Sci., 4(1):141150.

Banna, L., Darwish, R. M. and Aburjal, T. (2003). Effect of plant extracts and essential oils on root-knot nematode Phytopathol. Medit., 42: 123-128.

Chaudhary, K. K.; Haile, A.; Ayresea, Z. G.; Semereab, G. and Weldegergish, T. (2013). Nematicidal activity of Eritrean weed plants against the root-knot nematode Meloidogyne incognita (Kofoid and White) Chitwood. Nematro., 43:207-.215.

Chitwood, D. J. (2002). Phytochemical based strategies for nematode control. Ann. Rev. of Phytopathol.,40:221-249.

Chitwood, D. J. (2003). Research on the plant parasitic nematode biology conducted by the United States, Department of Agriculture Agricultural Research Service. Pest Manage Sci.,59:748-753.

El Allagui, N.; Tahrouch, S.; Bourijate, M. and Hatimi, A. (2007). Action differents extractsts végétaux sur la mortalité des nématodes à galles du genre Meloidogyne ssp. Acta Bot. Gallica, 154 (4):503-509.

Elbadria, G. A.; Leeb, D. W.; Parkc, J. C.; Yuc, H. B. and Chooc, H. Y. (2008). Evaluation of various plant extracts for their nematicidal efficacies against juveniles of Meloidogyne incognita. J. of Asia-Pacific Entomol., $11(2): 99-102$.

El-Hassan, M.; Ferji, Z. and Idrissi, H. L. (2013) Anti-nematode effect assessment of Peganum harmala based products against Meloidogyne javanica on melon. J. of Biolo, Agric. and Healthcare, 3 (5):2224-3208.

Facchini, P. J. (2001). Alkaloid biosynthesis in plants biochemistry, cell biology, molecular regulation, and metabolic engineering applications. Ann. Rev. of Plant Physiol. and Plant Molecular Biolo.,52: 29-66. 
Ferraz, S., and de Freitas, L. G. (2004). Use of antagonistic plants and natural products. Pp. 931-977 in Chen, Z. X., S. Y. Chen, and D. W. Dickson eds. Nematology-advances and perspectives, Volume II: nematode management and utilization. Cambridge, MA: CABI Publishing.

Goel, S. R.; Madan, V. K.; Sharma, K. K. and Nandal, S. N. (2005). Nematicidal activity of various medicinal and aromatic plants under in vitro conditions. National Symposium on Recent Advances and Research Priorities in Indian Nematol., 9-10 December, IARI, New Delhi, India, p.23.

Good, J. M.; Minton, N. A. and Joworsky, C. A. (1965). Relative susceptibility of selectedcover crops and coastal Bermudagrass to plant nematodes. Phytopathol., 55,1026-1030.

Javed, N.; Gowen, S. R.; Inam-ul-Haq, M. and Anwar, S. A. ( 2007a). Protective and curative effect of neem (Azadirachta indica) formulations on the development of root-knot nematode in roots of tomato plants. Crop Prot., 26:530-534.

Javed, N.; Gowen, S. R.; Inam-ul-Haq, M.; Abdullah, K. and Shahina, F. (2007b). Systemic and persistent effect of neem (Azadirachta indica) formulations against root-knot nematodes, Meloidogyne javanica and their storage life. Crop Prot., 26:911-916.

Khan, A.; Sayed, M.; Shaukat, S. S. and Handoo, Z. A. (2008). Efficacy of four plant extracts on nematodes associated with papaya in Sindh, Pakistan. Nematol. Medit., 36: 93-98.

Mhinana, Z.; Mayekiso, B. and Magwa, M. L. (2010). Anatomy and morphology of Nicotiana glauca with regard to its crystals characterization. Afr. J. Plant Sci., 4:172-178.

Mizrachi, N.; Levy, S. and Goron, Z. (2000). Fatal poisoning from Nicotiana glauca leaves: identification of Anabasine by Gas Chromatography/ mass Spectrometry. J. Forensic Sci., 45:736-741.

Mojumdar, V. and Mishra, S. D. (1991). Nematicidal efficacy of some plant products and management of Meloidogyne incognita in pulse crops by soaking seeds in their aqueous extracts. Current Nematol., 2: 27-32.

Moloudizargari, M.; Mikaili, P.; Aghajanshakeri, Sh.; Asghari, M. H. and Shayegh, J. (2013). Pharmacological and therapeutic effects of Peganum harmala and its main alkaloids. Pharmacognosy Rev., 7:199-212.

Moosavi, M. R. (2012). Nematicidal effect of some herbal powders and their aqueous extracts against Meloidogyne javanica. Nematrop., 42 (1): 48-56. 
Muniasamy, S.; Pavaraj, M. and Rajan, M. K. (2010). Efficacy of the fruit extract of Citrullus colocynthis (L.) on the root-knot nematode Meloidogyne incognita infecting Vigna ungiculata (L.). J. of Biopesticides, 3(1):309-312.

Nandal, S. N. and Bhatti, D.S. (1986). The effect of certain edaphic factors on the nematicidal activity of plant extracts. Nematologia Medit., 14:295-298.

Nelaballe, V. K. and Mukkara, L. D. (2013). A Preliminary study on the nematicidal effect of some local flora on Meloidogyne incognita Chit wood infesting mulberry. Internatio. J. of Chemical, Environmental \& Biological Sci. (IJCEBS) 1(3) ISSN 2320-4079; EISSN 2320-4087.

Neves, W. D. S.; Freitas, L. G. D.; Giaretta, R. D.; Fabry, C. F. S., Coutinho, M. M.; Dhingra, O. D.; Ferraz, S. and Demuner, A. J. (2005). Activity of garlic, mustard and chili pepper extracts on Meloidogyne javanica egg hatch. Nematologi. Brasileira., 29(2): 273-278.

Parihar, K.; Rehman, B. and Siddiq, A. S. (2012). Impact of organic additives for sustainable management of root-knot nematode in bottle gourd. Biosciences International, 1(4): 102-105.

Patel, A.D.; Patel, D. J. and Patel, N. B. (2004) Effect of aqueous leaf extracts of botanicals on egg hatching and larval penetration of Meloidogyne incognita in banana. Indian J. Nematol., 34: 37-39.

Pavaraj, M., Karthikairaj, K. and Baskaran, S. (2012). Evaluation of some plant extracts for their nematicidal properties against root-knot nematode, Meloidogyne incognita. J Biopest, 5 (Supplimentary): 106-110.

Pavaraj, M.,; Karthikairaj, K. and Rajan, M. K. (2010). Effect of leaf extract of Ageratum conyzoides on the biochemical profile of blackgram Vigna mungo infected by root-knot nematode, Meloidogyne incognita. J. of Biopesticides, 3(1): 313-316.

Pavela, R. (2004). Insecticidal activity of certain medicinal plants. Fitoterapia, 75:745-749.

Pluke, R.; Permaul, D. and Leibee, G. (1999). Integrated pest management and the use of botanicals in Guyana. Inter-American Institute for Cooperation on Agric. Guyana,, Univ. of Guyana, 142 pp.

Prasad, D.; Ram, D. and Imtiyaz, A. (2002). Management of plant parasitic nematodes by the use of botanicals. Ann. of Plant Protect. Sci., 10(2): 360364.

Qamar, F.; Kapadia, Z.; Khan, S. A. and Badar, Y. (1995). Datura metel L., a plant with nematicidal potential. Pak. J. Sci. Ind. Res., 38: 319-321. 
Rizvi, R.; Mahmood, I..; Tiyagi, S. A and Khan, Z. (2012). Effect of some botanicals for the management of plant-parasitic nematodes and soilinhabiting fungi infesting chickpea. Turk J. Agric. For., 36:710-719.

Saeed, M. R. and Shawkat, J. N. (2014). Evaluation of nematicidal effect of some botanical powders and poultry manure against the root-knot nematode Meloidogyne incognita in tomato plants under greenhouse conditions. Egypt. J. Agronematol., 13 (1):160 -171.

Saleh, M. A.; Abdel Rahman, F. H.; Ibrahim, N. A. and Taha, N. M. (1987). Isolation and struture determination of new nematicidal triglyceride from Argemone mexicana. J. of Chemical Ecol., 13: 1361 - 1370.

Sasser, J. N. (1979). Economic importance of Meloidogyne in tropical countries, In: Lamberti F, Taylor CE (eds), Root-Knot Nematodes (Meloidogyne species) Systematics, Biology and Control, Academic Press Inc،. London and New York, 341-374.

Sasser, J. N. and Freckman, D. W. (1987). A world perspective on nematology the role of the society. In: Vistas on Nematology (Eds. JA Veech, DW Dickson). Society of Nematologists, Hyattsville, Maryland, USA, pp. 7-14.

Sellami, S. and Mouffarrah, A. (1994). Effect of some aqueous plant extracts on juvenile hatching and larval mortality against $M$. incognita. Mededelingrn Faculteit- Landbouwkundige-en Toegepaste-Biologi sche- Wetensch appen Universiteit - Gent, 59(26): 813-816.

Shahwar, D.; Abid, M.; Rehman, A. U.; Maqbool, M. A. and Choudhary, M. I. (1995). Nematicidal compounds from Datura fastuosa..: Eds. A.U. Rehman, M.A. Choudhary and M.S. Sheikhani. In the Proc. $19^{\text {th }}$ IURC Symposium on the Chemistry of Natural Products. HEJ Res. Inst. of Chemistry, University of Karachi 75270-Pakistan, pp: 171-179.

Sharma, N. and Trivedi, P. C. (2002). Screening of leaf extracts of some plants for their nematicidal and fungicidal properties against Meloidogyne incognita and Fusarium oxysporum. Asian J. Exp. Sci., 16:21-28.

Shaukat, S. S.; Siddiqui, I. A.; Khan, G. H. and Zaki, M. J. (2002). Nematicidal and allelopathic potential of Argemone mexicana, a tropical weed. Plant and Soil, 245:239-247.

Sholevarfard, A. R. and Moosavi, M. R. (2015). The potential of separate and combined application of some plant extracts and defense inducer molecules for controlling of Meloidogyne javanica. Nematrop., 45:82-95.

Siddiqi, M. R. (2000). Tylenchida Parasites of plants and insects ( $2^{\text {nd }}$ editon). CABI Publishing, CAB International, Wallingford. 
Tibugari, H.; Mombeshora, D.; Mandumbu, R.; Karavina, C. and Parwada, C. (2012). A comparison of the effectiveness of the aqueous extracts of garlic, castor beans and marigold in the biocontrol of root-knot nematode in tomato. J. of Agric. Techno., 8(2): 479-492.

Webb, M. and Dalzell, S. (1997). Nicotiana glauca toxicity. Emergency Med.,9:2528.

Zasada, I. A.; Ferris, H. and Zheng, L. (2002). Plant sources of Chinese herbal remedies: laboratory efficacy, suppression of Meloidogyne javanica in soil, and phytotoxicity assays. J. of Nematol., 34:124-129.

Zongo, J. O.;Vincent, C. and Stewart, R. K. (1993). Effects of neem seed kernal extracts on egg and larval survival of the sorghum shot fly, Atherigona soccata Rondani (DipterMuscidae), J. of Applied Entomol., 115:363-369. 


\section{الملخص العربي}

\section{التأثير الإبادي لمستخلص عشر أنواع نباتية}

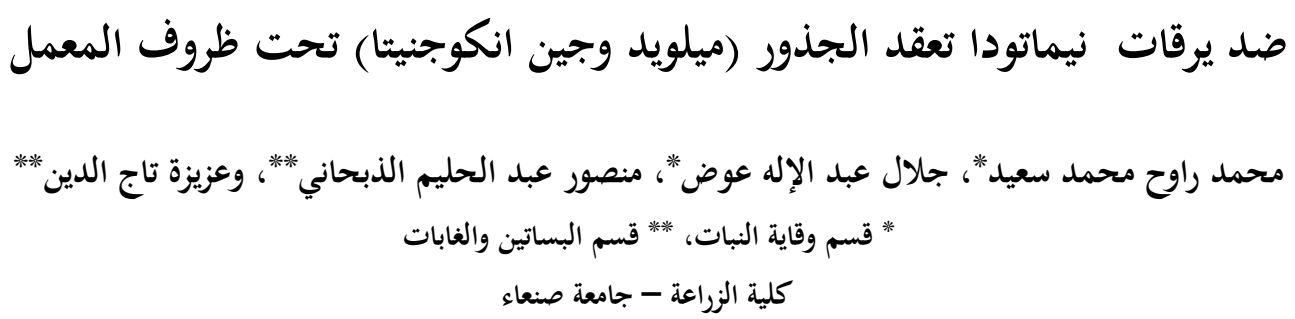

تحت ظروف المعمل تم دارسة الكفاءة الإبادية للمستخلصات المائية لأوراق عشرة أنواع نباتية

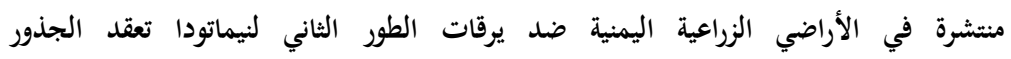
Meloidogyne incognita

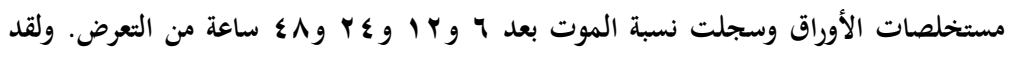

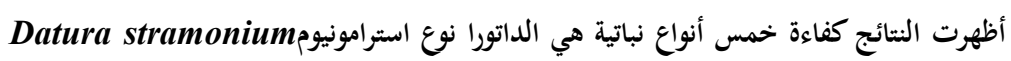

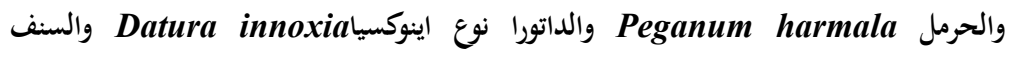

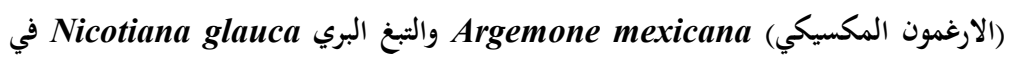

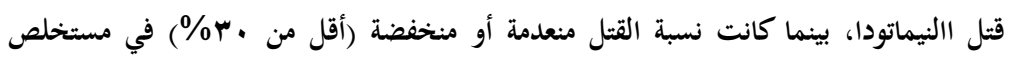

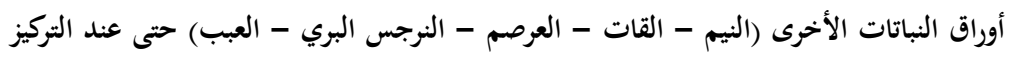

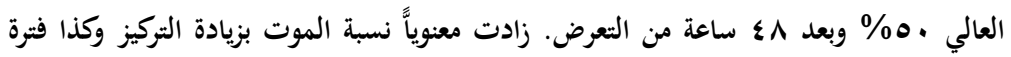

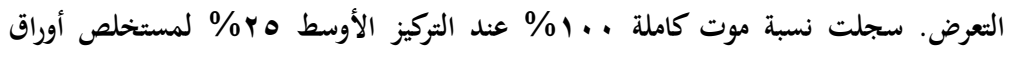

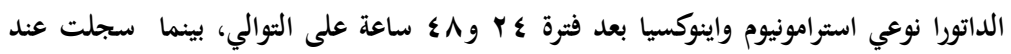

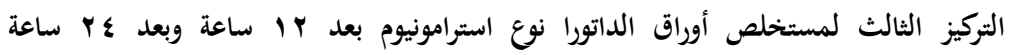

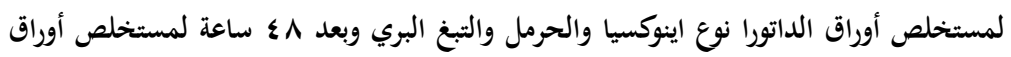

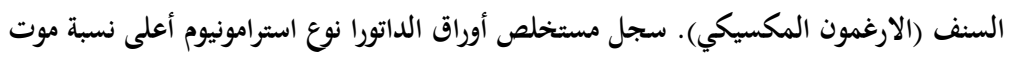

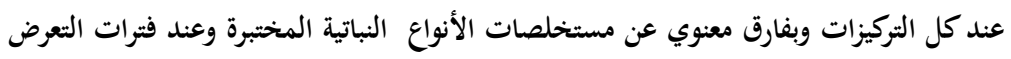
المختلفة. 